\title{
Towards a global history of agricultural systems
}

Mats Widgren

\section{Maps of past agricultural systems suggest two rapid changes: around $1500 \mathrm{CE}$, as European colonization led to demographic and agricultural collapse in South America, 1870 to 1920 CE, as industrialization and steam transport resulted in a global division of labor.}

Historians, archaeologists and historical geographers have been slow in reacting to the increased interest from climate modelers in past land use. However, the research situation for the Americas in the wake of the 500-year anniversary in 1992 of Columbus's travels did stimulate syntheses on pre-Columbian landscapes (Butzer 1992). Three volumes on the cultivated landscapes of native America were published by Doolittle (2000), Denevan (2001), and Whitmore and Turner (2001). The subsequent dissemination of these syntheses to a broader audience by Mann (2005) should also be mentioned. These studies and publications inspired a cooperative effort by a group of American and Swedish scholars to map the development of global agricultural systems over the last 1000 years under the framework of the project Mapping Global Agricultural History (Widgren 2010). Here, we present, as an example, one of the maps created within the project: agricultural systems in Africa around $1800 \mathrm{CE}$. We based the development of global categories on the previous work of Whittlesey (1936) and Grigg (1974) on global agricultural regions in the 20th century. We are not mapping land cover, per se, or land-use types, but rather a limited set of globally known agricultural systems, i.e. the presence of agriculture and the dominant type of agricultural system. It is not possible to translate the mapped information into areas of different land-cover or land-use types. For example, a single agricultural system, i.e. mixed farming, was dominant in Northern Europe, where the activities related to crop cultivation and livestock were closely integrated. Land use and land cover could, however, vary widely, from large open fields in the Paris basin to remote farms in northern Scandinavia, where forest was the dominant land cover (Grigg 1974). Presentation of our knowledge on agrarian systems at the global scale in maps nevertheless facilitates comparison with other data and model simulations on land use and land cover.

We have striven to keep the number of categories low in order to increase read ability of the maps. On the global scale we defined; (1) Pastoralism and ranching, (2) Husbandry of non-domesticated plants, (3) Extensive or undifferentiated agriculture, (4) Permanent fields, (5) Mixed farming, (6) Intensive systems, and

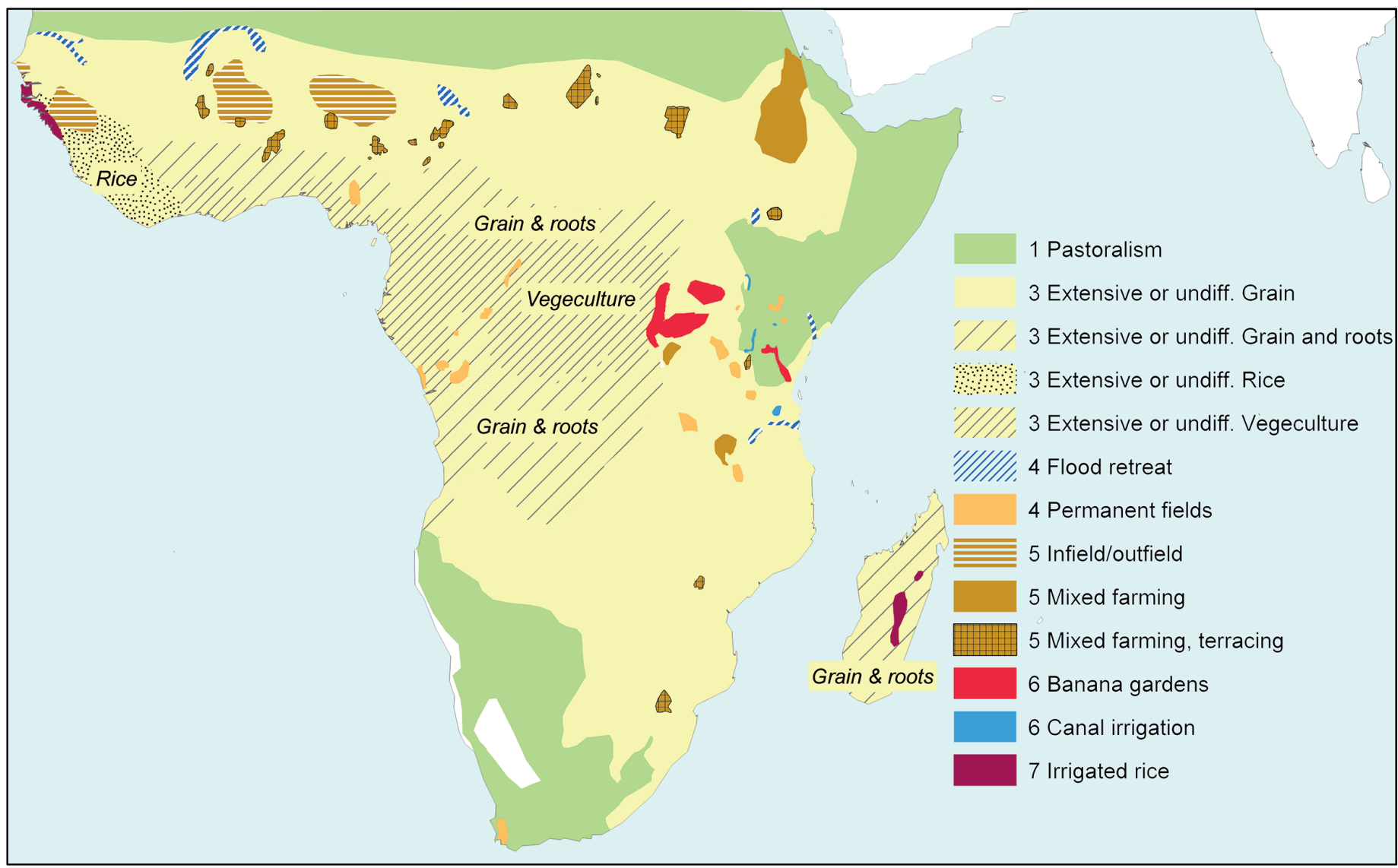

Figure 1: Agricultural systems in sub-Saharan Africa by 1800 CE. Husbandry of non-domesticated plants (category 2) certainly did exist in Africa, but was practiced in pockets within larger regions of agriculture and has therefore not been mapped. The background data for the map and the GIS-file can be downloaded from Widgren (2017). 


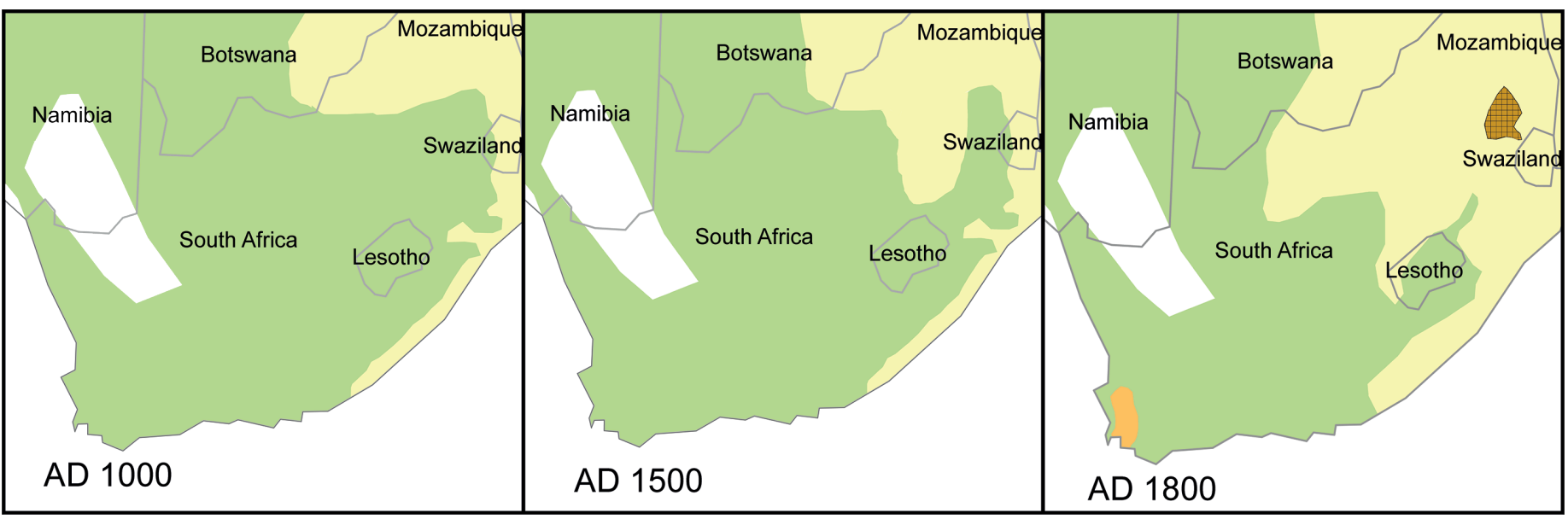

Figure 2: Agricultural expansion in Southern Africa CE 1000 to 1800. Based on Maggs (1984) and Christopher (1982). For explanations, see caption of Fig. 1.

(7) Irrigated rice. This classification system is open for discussion and can have advantages or disadvantages depending on different viewpoints and aims. It has proven, however, to work on a global level and make comparisons across and between continents possible. Agricultural systems should preferably be understood on a nominal scale because they are qualitatively different and not immediately possible to translate into an ordinal scale. However, differences in productivity, labor intensity, and in the degree of modification of the land have inspired us to introduce an ordinal scale in the numbering and coloring of the systems. For the continental maps, each category can be further subdivided, as in Figure 1. For a discussion of the global categories and the continental sub-categories for Africa, see Widgren (in press).

In contrast with anthropogenic landcover change (ALCC) scenarios like those published by Kaplan et al. (2009) or Klein Goldewijk et al. (2017), we can show particularly rapid changes - "leaps" - that were due to global historical and political events. Such a "leap" occurred when the European colonization of South America (ca. $1500 \mathrm{CE}$ ) led to a demographic and agricultural collapse, especially in the Amazon. The other most important leap is the expansion of farming in the second half of the 19th century, when the combination of industrialization and steam transport led to a global division of labor on an unprecedented scale. It is in that context that we can see the expansion of the wheat frontier in western USA and eastern Eurasia, and at the same time a rapidly expanding rice frontier in the outer parts of the Asian deltas. Any modeling based on population growth and per capita consumption in different regions becomes increasingly meaningless from this period onwards.

The historical development of farming in Southern Africa exhibits another trajectory that is difficult to model if archaeological and historical data are not taken into account. Archaeologists and historians have known for a long time that the winter rainfall area of Western
Cape cannot sustain the African crops sorghum and millet. The agricultural development of African populations hence came to a definite limit in its expansion towards the southwest. It was only with the introduction of European crops that a Mediterranean type of farming system was established. Nonetheless, European farming had only reached a small area of the Western Cape around $1800 \mathrm{CE}$ (see Maggs 1984 for the archaeological evidence, and Christopher 1982 for the historical evidence of European farming). Recent work based on a large archaeological database for Southern Africa seems to confirm Maggs' maps of precolonial farming communities and provides a strong potential for a more precise mapping of agriculture in Southern Africa (Russell et al. 2014).

The Mapping Global Agricultural History project and PAGES' Land Cover6k have the goal to provide evidence of landuse change at the global scale based on empirical data. Thanks to those activities, we expect this type of information will become more common. However, it is still a challenge to transparently integrate this empirical knowledge in the model-based back-casting that has so far dominated historical land-cover and land-use studies.

\section{ACKNOWLEDGEMENTS}

The work on the definition of global categories and the continental maps within the Mapping Global Agricultural History project was performed with Bill Doolittle (University of Texas-Austin), Ulf Jonsson (Stockholm University), Janken Myrdal (Swedish University of Agricultural Science), Mats Widgren (Stockholm University) and Bill Woods (1947-2015 University of Kansas). Clark Erickson (University of Pennsylvania) has now joined that team to replace Bill Woods. In the context of PAGES LandCover6k, regional subgroups carry out the work in Africa. The group for Southern Africa includes Matthew Hannaford (Utrecht University), Munyaradzi Manyanga (University of Zimbabwe), Thembi Russel (University of the Witwatersrand) and the author (Stockholm University). A first version of the results for Southern Africa will be presented at the 15th Congress of PanAfrican Archaeological Association for Prehistory and Related Studies (PanAf) in Rabat, Morocco, 10-14 September 2018.

\section{AFFILIATION}

Department of Human Geography, Stockholm University, Sweden

CONTACT

Mats Widgren: mats.widgren@humangeo.su.se

\section{REFERENCES}

Butzer KW (1992) Ann Assoc Am Geogr 82: 345-368 Christopher AJ (1982) S Afr Geogr J 64: 97-113 Denevan WM (2001) Cultivated landscapes of native Amazonia and the Andes: triumph over the soil. Oxford University Press, 432 pp

Doolittle WE (2000) Cultivated landscapes of native North America. Oxford University Press, 600 pp

Grigg DB (1974) The agricultural systems of the world: an evolutionary approach. Cambridge University Press, $372 \mathrm{pp}$

Kaplan JO et al. (2009) Quat Sci Rev 28: 3016-3034 Klein Goldewijk K et al. (2017) Earth Syst Sci Data 9: 927-953

Mann CC (2005) 1491: new revelations of the Americas before Columbus. 1st ed. Knopf, 465 pp

Maggs T (1984) In: Klein RG (Ed) Southern African prehistory and paleoenvironments. Balkema 329-360

Russell T et al. (2014) PLoS ONE 9: e87854

Whittlesey D (1936) Ann Assoc Am Geogr 26: 199-240

Whitmore TM, Turner BL (2001) Cultivated landscapes of middle America on the eve of conquest. Oxford University Press, $330 \mathrm{pp}$

Widgren M (2010) In: Kinda A et al. (Eds) Proceedings of the 14th International Conference of Historical Geographers, Kyoto 2009. Kyoto University Press, 211-212

Widgren M (2017) A map of agricultural systems in Africa by 1800 . Figshare

Widgren M (in press) In: Mercuri AM et al. (Eds) Plants and Humans in the African Past - Progress in African Archaeobotany, Springer 